
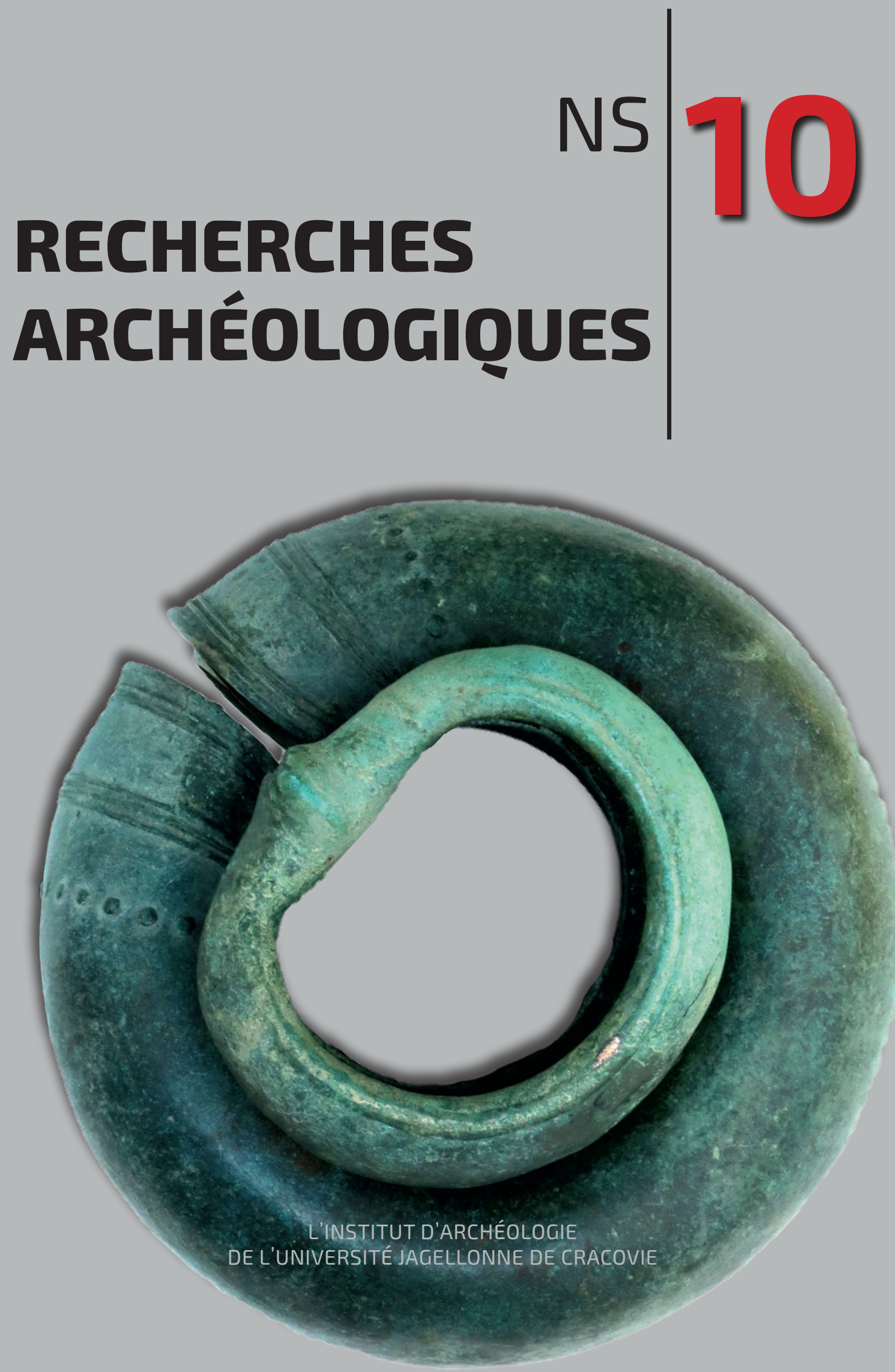
RECHERCHES ARCHÉOLOGIQUES NOUVELLE SERIE 

L'INSTITUT D'ARCHÉOLOGIE

DE L'UNIVERSITÉ JAGELLONNE DE CRACOVIE

RECHERCHES ARCHÉOLOGIQUES

NOUVELLE SERIE 10

(2018)

KRAKÓW 2019 
(C) Copyright by Institute of Archaeology of the Jagiellonian University, Kraków 2019

\author{
RÉDACTEUR EN CHEF \\ Przemysław Nocuń \\ SÉCRETAIRE DE LA RÉDACTION \\ Michał Kasiński \\ COMITÉ DE RÉDACTION
}

Jan Chochorowski, Krzysztof Ciałowicz, Ulla Lund Hansen, Renata Madyda-Legutko, Vjacheslav I. Molodin, Ewdoksia Papuci-Władyka, Jacek Poleski, Pál Raczky, Paweł Valde-Nowak

RÉDACTEURS DU SUJET

Wojciech Blajer, Janusz Ostrowski, Krzysztof Sobczyk, Joachim Śliwa

COMITÉ DE LECTURE

Dagmara Adamska, Justyna Baron, Małgorzata Chorowska, Adam Cieśliński, Katarzyna Czarnecka, Przemysław Dulęba, Jan Jílek, Maciej Kaczmarek, Andrzej Maciałowicz, Marcin Maciejewski, Kyrilo Myzgin, Marcin S. Przybyła, Marzena Przybyła, Tomasz Ratajczak, Judyta Rodzińska-Nowak, Sławomir Sprawski, Michał Wojenka

ÉDITEURS DE LANGUE

Piotr Godlewski, Keith Horechka

MAQUETTE DE COUVERTURE, MISE EN PAGES

Wydawnictwo i Pracownia Archeologiczna PROFIL-ARCHEO Magdalena Dzięgielewska

ADRESSE DE LA RÉDACTION

Instytut Archeologii Uniwersytetu Jagiellońskiego, ul. Gołębia 11, PL 31-007 Kraków

www.farkha.nazwa.pl/RechACrac/

www.archeo.uj.edu.pl/RechACrac/

La version originale des Recherches Archéologique Nouvelle Serie est la version papier

"Recherches Archéologiques Nouvelle Serie" est régulièrement sur la liste dans The Central European Journal of Social Sciences and Humanities

Podniesienie poziomu umiędzynarodowienia tomów nr 9 i 10 czasopisma "Recherches Archéologiques, Nouvelle Serie" - zadanie finansowane w ramach umowy nr 606/P-DUN/2018 ze środków Ministerstwa Nauki i Szkol-

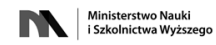
nictwa Wyższego przeznaczonych na działalność upowszechniającą naukę

ISSN 0137-3285

Publikacja finansowana przez Uniwersytet Jagielloński

Cette publication est financée par l'Université Jagellonne 


\section{CONTENU}

\section{ÉTUDES}

Wojciech Blajer: Some remarks on socketed axes of the Passau type

Karol Dzięgielewski, Anna Longa, Jerzy Langer, Magdalena Moskal-del Hoyo: Contextualisation of the Early Iron Age hoard of bronze objects discovered in Gdynia-Karwiny, site 1

Przemysław Dulęba: New data for studies on settlement and economy of the La Tène culture in Lower Silesia

Przemysław Dulęba: La Tène culture in Silesia. Remarks on the state of research and new cognitive perspectives

Krzysztof Michalczewski, Jan Bulas: Flat scrapers made of bone from Pre-Roman and Roman Period on the Polish Lands

Dariusz Niemiec: $13^{\text {th }}$-century fortifications of Kraków

Jarosław Bodzek, Kamil Kopij, Szymon Jellonek, Barbara Zając: Studies on Roman coin finds from the Central European Barbaricum in the Institute of Archaeology of the Jagiellonian University - an overview

\section{RAPPORTS}

Michał Kasiński, Jan Bulas, Magdalena Okońska: A newly discovered Przeworsk culture settlement and burial ground from the Late Pre-Roman and Roman period at Bejsce, Dist. Kazimierza Wielka - preliminary results of field-walking survey and rescue excavations

Joanna Zagórska-Telega, Jacel Pikulski, Anita Szczepanek: Archaeological excavations of multicultural site 1 at Michałowice, Commune Czarnocin, in seasons 2013-2014

Paulina Kowalczyk-Matys: Figural tile from the first half of the $16^{\text {th }}$ century with a young man from Jagiellońska Street in Kraków 
Joanna Zagórska-Telega ${ }^{1}$, Jacek Pikulski, Anita Szczepanek ${ }^{2}$

\title{
Archaeological excavations of multicultural site 1 at Michałowice, Commune Czarnocin, in seasons 2013-2014
}

\begin{abstract}
The excavations of multicultural site 1 at Michałowice have been carried out since 2008. So far, the excavations have encompassed approx. 40 ares and resulted in the discovery of 122 archaeological features. The area investigated in seasons 2013-2014 totals 10 ares. The research revealed cremation burials associated with the Lusatian and Przeworsk cultures, as well as the first inhumation burial in the site, and more groove features linked with the Przeworsk culture.
\end{abstract}

Keywords: cemetery, Lusatian culture, Przeworsk culture, Bronze Age, Roman Period, inhumation grave, groove features

\section{Introduction}

The excavations carried out in 2013-2014 were continuation of research conducted in site 1 at Michałowice since 2008. A total of 122 archaeological features have been discovered so far, most of them linked with a Przeworsk culture cemetery. The site has also yielded Trzciniec culture inhumation burials of humans and animals and Lusatian culture cremation burials, as well as a number of pits of undetermined chronology (cf. Pikulski, Zagórska-Telega 2011; ZagórskaTelega, Bulas, Pikulski, Szczepanek 2011; Zagórska-Telega, Pikulski, Bulas, Szczepanek 2012; Zagórska-Telega, Pikulski 2014; Zagórska-Telega, Pikulski, Szczepanek 2015) (Fig. 1-2). ${ }^{3}$

The research in 2013 was concentrated in the south-western part of the site. Among the explored features were ten significantly damaged features which, after preliminary analysis, should be linked with the Lusatian culture, as well as three groove features, cremation burials, and an inhumation burial, all linked with the Przeworsk culture cemetery. In 2014 two features of non-anthropogenic nature were discovered.

1 Institute of Archaeology, Jagiellonian University; 11 Gołębia St., 31-007 Kraków, Poland; zagorskaster@gmail.com

2 Department of Anatomy, Jagiellonian University Medical College; 12 Kopernika St., 31-034 Kraków, Poland; anita.szczepanek@uj.edu.pl

3 Test excavations were carried out in the site in 1982 and 1990-1991 (cf. Kaczanowski, MadydaLegutko, Poleski 1984). 


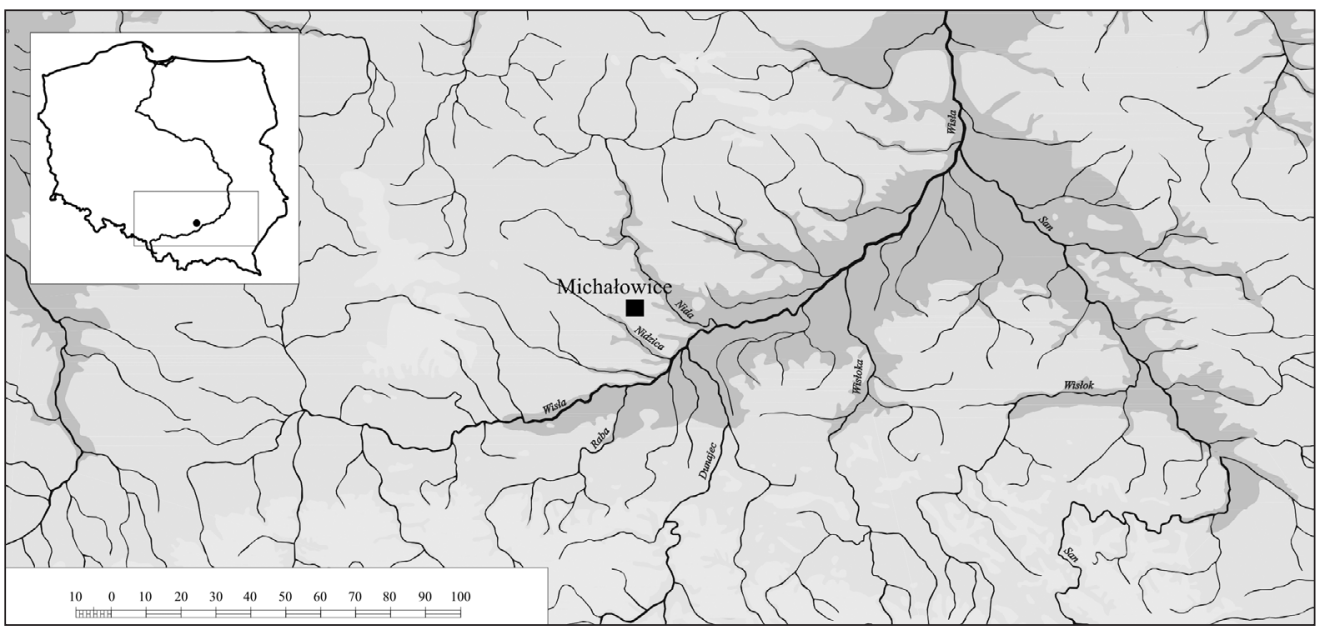

Fig. 1. Michałowice, Czarnocin commune, site. 1. Location of the site

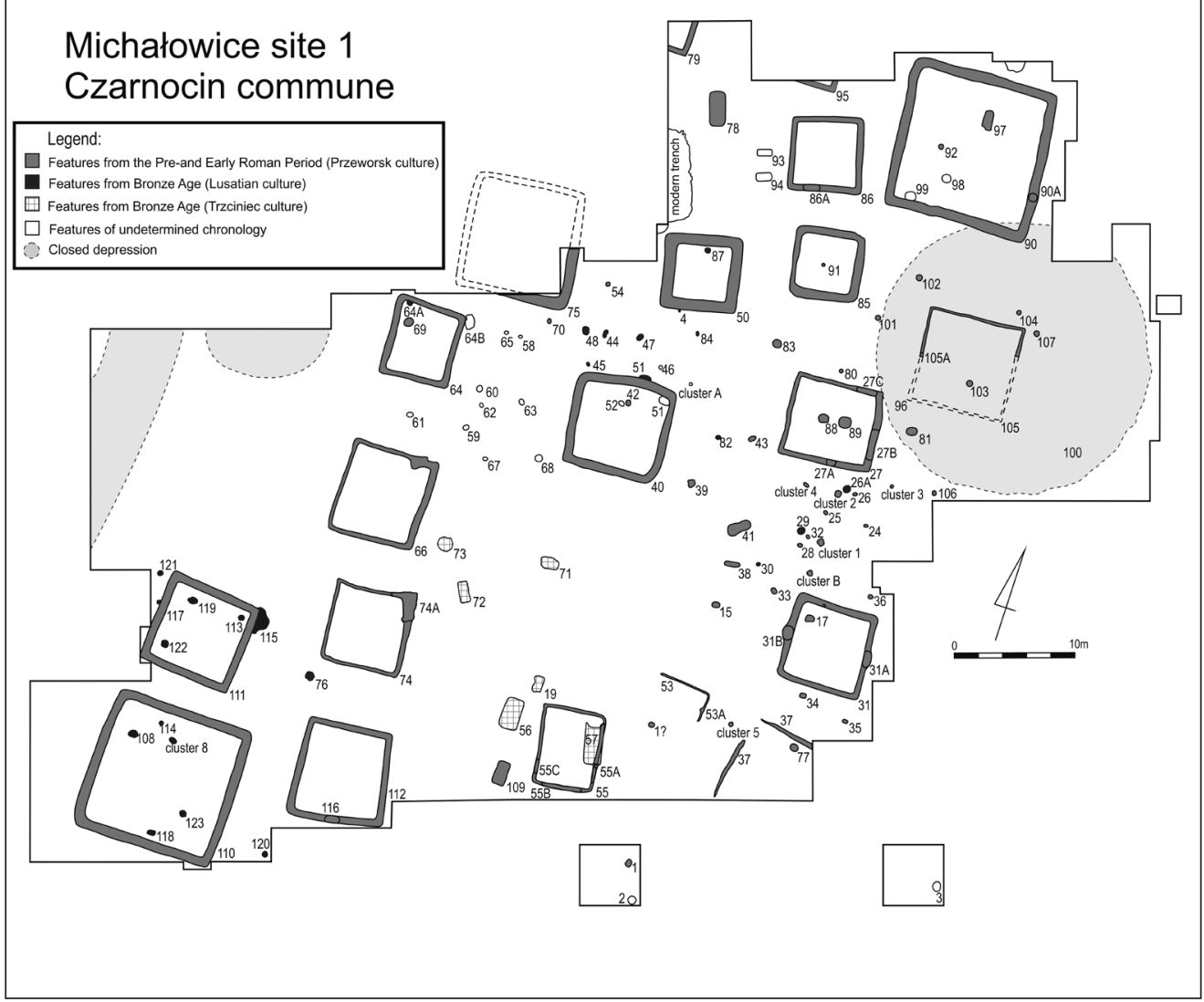

Fig. 2. Michałowice, Czarnocin commune, site. 1. Plan of the cemetery 


\section{Archaeological features}

Cluster 8 and features 108, 113, 114, 117, 118, 119, 120, 121, 122, 123 should be assigned to the Bronze Age (Lusatian culture). They were identified immediately beneath the topsoil as small depressions containing archaeological materials in varying states of preservation - from identifiable vessel forms to highly fragmented and dispersed potsherds and cremated bones.

Of particular note among the Lusatian culture features is the considerably damaged feature 108, which contained numerous potsherds originating from several vessels, including a fully preserved small vase with rounded body and two handles (Fig. 3: 2). Undecorated vessels of that kind, with conical or cylindrical necks and provided with two handles set at the base of the neck, are not precise chronological indicators. They can be encountered in graves from Bronze Age Period III and in later assemblages, until the Hallstatt period (Gedl 1962, 23; Miśkiewicz 1968, 146; Konieczny 2014, 117). In the site of Targowisko, Dist. Wieliczka, such forms cooccur with vessels characteristic of Period IV (Konieczny 2014, 120).

Feature 108 also yielded an undecorated, gently profiled vase, damaged in the upper part (Fig. 3: 1). It is a commonplace form in Lusatian culture cemeteries in Period IV (Gedl 1962, 20; 1982, 22-23; 1989, 15; 1991, 23), and sometimes in early Period V as well (Miśkiewicz $1968,143)$. In the same feature a fragment of a biconical, sharply profiled vase decorated with incised horizontal lines and stylised herringbone motifs was also found (Fig. 3:3). Vases of that kind, with a sharp or sometimes more gently marked shoulder, less than $20 \mathrm{~cm}$ high, typically with thin- or middle-thick walls and with a smoothened, shining external surface, are known from Lusatian culture sites. Their decoration with horizontal lines, strokes, dots, zigzags, and hatched motifs arranged in geometric patterns is quite common, which also applies to stylised herringbone motifs and triangles. Typically, the decoration featuring on a vessel is a combination of different motifs (Konieczny 2014, 121, fig. 19). Vases of this type are common in cemeteries from the older section of Period IV (HaA2) (Durczewski 1948, 43, pl. LXXXIII: 2, 3, 10; Kogus 1963, pl. III: 6; Gedl 1982, 23-24; Reguła 1997, 214, fig. 6: c; Fraś, Reguła 2003, fig. 4: e; Konieczny 2012, 374; Górski 2018, 55).

Also of note are two vessels found adjoining each other during the exploration of groove feature 111, which were designated as feature 113. They were found immediately beneath the topsoil, in dark-brown subsoil with no traces of a pit detectable (cf. Fig. 8). It is worth noting that no bones were found, neither in the vessels nor in their immediate vicinity. Both vessels had their upper parts damaged by deep ploughing. The larger one is a biconical vessel decorated with a combination of incised lines, dots, and "wolf teeth" motifs (Fig. 3: 5), a very characteristic ornamentation known as the Urad style. Vessels decorated in this manner occur in many local groups within the Lusatian culture, and in western Małopolska they are sometimes referred to as "Zofipole vases" (Górski 2014, 216) because many specimens representing this style are known from the site of Zofipole, Dist. Kraków. However, in the Zofipole cemetery these vessels, which were used there as cinerary urns, were considerably larger (Żaki 1950, 179-181, fig. 16-18). Vases in question occur in the older phase of Period IV (HaA2), synchronised with phase III of the Kietrz cemetery (Gedl 1979, fig. 5). Analogical decoration with broken lines running from the apex of the largest triangles was also recorded in the cemetery at KrakówBieżanów, Dist. Kraków, site 30 (Fraś, Reguła 2003, fig. 4: e). Feature 113 also yielded a small sharply profiled vase (Fig. 3: 4), a type of vessel which also should be linked with Period IV (Konieczny 2014, 121).

Very close to groove feature 111 and the above-mentioned feature 113 other features associated with the Lusatian culture were found $(117,119,121)$. They, too, were badly damaged 

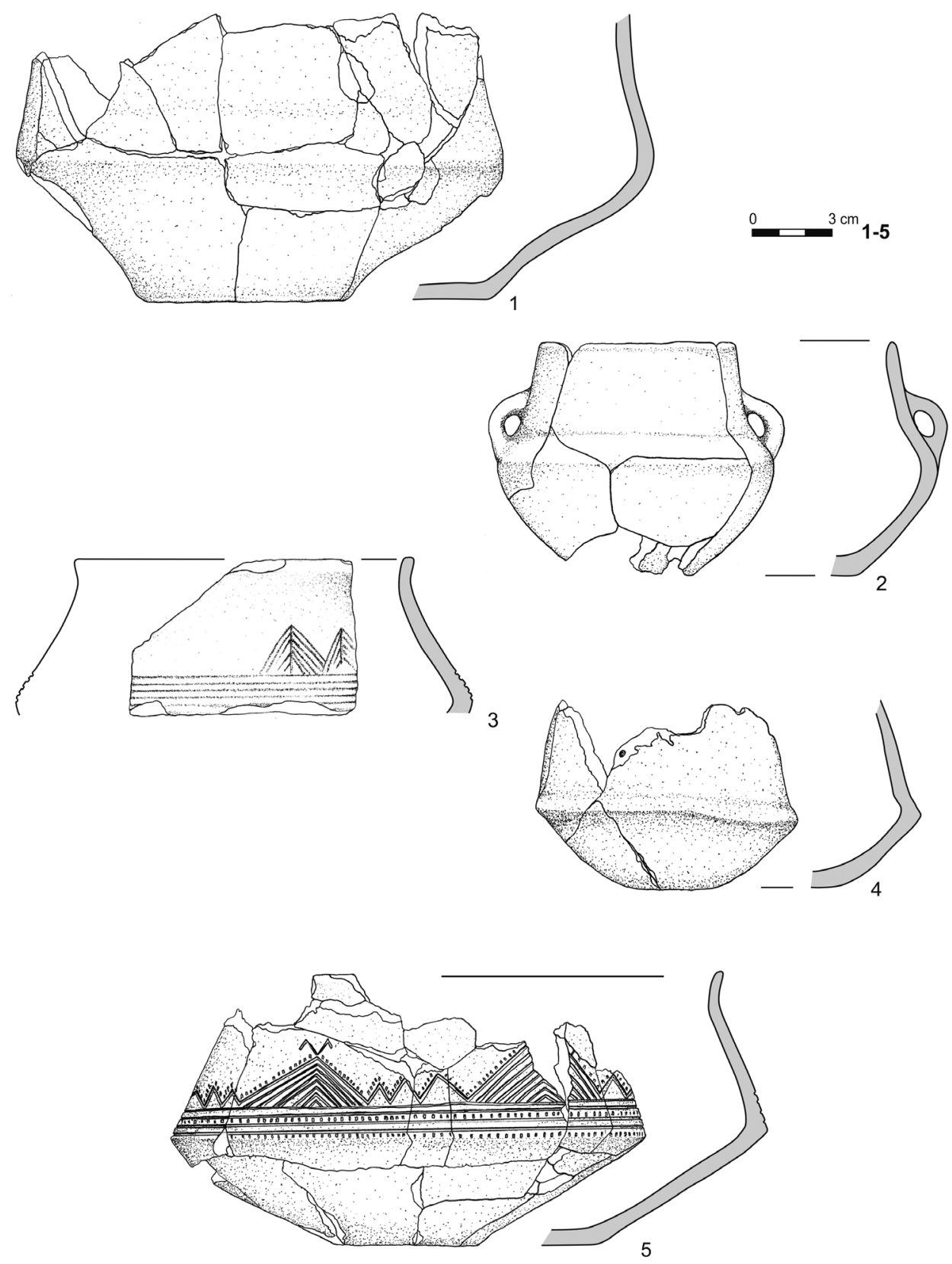

Fig. 3. Michałowice, Czarnocin commune, site. 1. Grave goods from features $108(1-3)$ and $113(4,5)$; (1-5) - clay. Drawn by P. Cyganiewicz, M. Okońska and J. Zagórska-Telega 
by agricultural activity and, as one can suppose, by Przeworsk culture features as well. Features 119 and 121 produced fragments of broad-mouthed profiled bowls (Fig. 4: 1, 2). The one from feature 121 had a ribbon-like handle preserved. In cemeteries, bowls were most often used as urn covers or accompanying vessels, less often as urns (Konieczny 2014, 127). Such vessels are not good chronological indicators, since they occur throughout the entire period of Lusatian culture development, although with the highest frequency recorded in the early phases (Gedl 1982, 16). They can be found in cemeteries dated to Period III: at Iwanowice, Dist. Kraków (Kozłowski 1920, 49, 53), Zofipole, Dist. Kraków (Żaki 1950, figs 52, 54, 57), Kraków-Pleszów, Dist. Kraków, site 17 (Kogus 1963, pl. I: 3, 6; II: 6), Kraków-Bieżanów, Dist. Kraków, site 30 (Konieczny 2012, 378; cf. also Gedl 1984, 57; 1991, 24; 1992, 19). They are also known from a Period IV cemetery at Targowisko, Dist. Wieliczka, linked with the Zofipole-Raciborsko phase (Gedl 1982, 23-24), distinguished by a strong similarity to the Silesian group (phase Kietrz III) (Konieczny 2014, 127, fig. 23).

The considerable extent of damage and complex redeposition processes in the site are wellreflected by the fact that fragments of the same vessels were found in different features. This was the case with features 118 and 123 . They were discovered close to each other, in the immediate vicinity of groove feature 110 (in the area enclosed by the arms of the groove). Both features yielded only fragments of damaged vessels, occurring immediately beneath the topsoil. The conjoining fragments originate from at least two vessels. One is a vase with a rounded body, decorated with deep, arching flutes surrounding small protuberances placed at the maximum body diameter, known as a "pseudo-bossed" ornament. Flutes also feature on the vertical neck. The vessel was provided with two small handles placed at the transition of the body and neck (Fig. 4: 3). A vessel with a similar decoration was also found in a secondary context in the fill of groove feature 110. Vessels of that type are known from the Targowisko cemetery (Konieczny 2014, pl. 125: c, 241: m) and from the settlement at Kraków-Pleszów (Kogus 1982, 340, pl. IV: 5), and are typical of the Lusatian culture pottery style in Period IV (HaB) (Gedl 1982, 24); their origin should probably be sought on the other side of the Carpathians (Górski 2018, 550). The other reconstructed vessel is a small scoop with the base of the handle preserved (Fig. 4: 4). The upper part of the vessel has not survived, making the reconstruction of the original shape impossible, although one can suppose that it was conical in shape. This, however, does not offer sufficient grounds for dating the vessel with more precision, since these are long-lasting forms, admittedly with the highest frequency in inventories dated to Period IV (Gedl 1962, 44; Durczewski 1946, 67).

It is also worth noting a small vessel fragment found in the fill of groove feature 110, which represents a middle part of a vessel, most likely a small goblet or vase, decorated in the preserved part with a band of vertical flutes (Fig. 4: 5). The small size of the sherd does not allow for the reconstruction of the full shape, although the characteristic ornamentation suggests dating within Period IV (Gedl 1982, 23-24).

In the $\mathrm{N}$ arm of groove feature 110 a fragment of a bronze object was discovered, in a secondary context. The state of preservation hampers its identification, although one can suppose with certain degree of likelihood that it is a fragment of a binocular pendant. The artefact obviously originates from a damaged Lusatian culture burial. Such pendants are not good chronological indicators: they became popular in Period III and remained in use throughout the entire period when the Lusatian culture developed (Miśkiewicz 1968, 158; Gedl 1987, 20-21; Bajda-Wesołowska, Bochnak, Hozer 2014, 118). Similar specimens are also known from the Trzciniec culture milieu (see e.g. Panasewicz, Taras 2007, 269).

It is worth noting that throughout all excavation seasons only small amounts of cremated human bones, or no bones at all, were recorded in features associated with the Lusatian culture. 

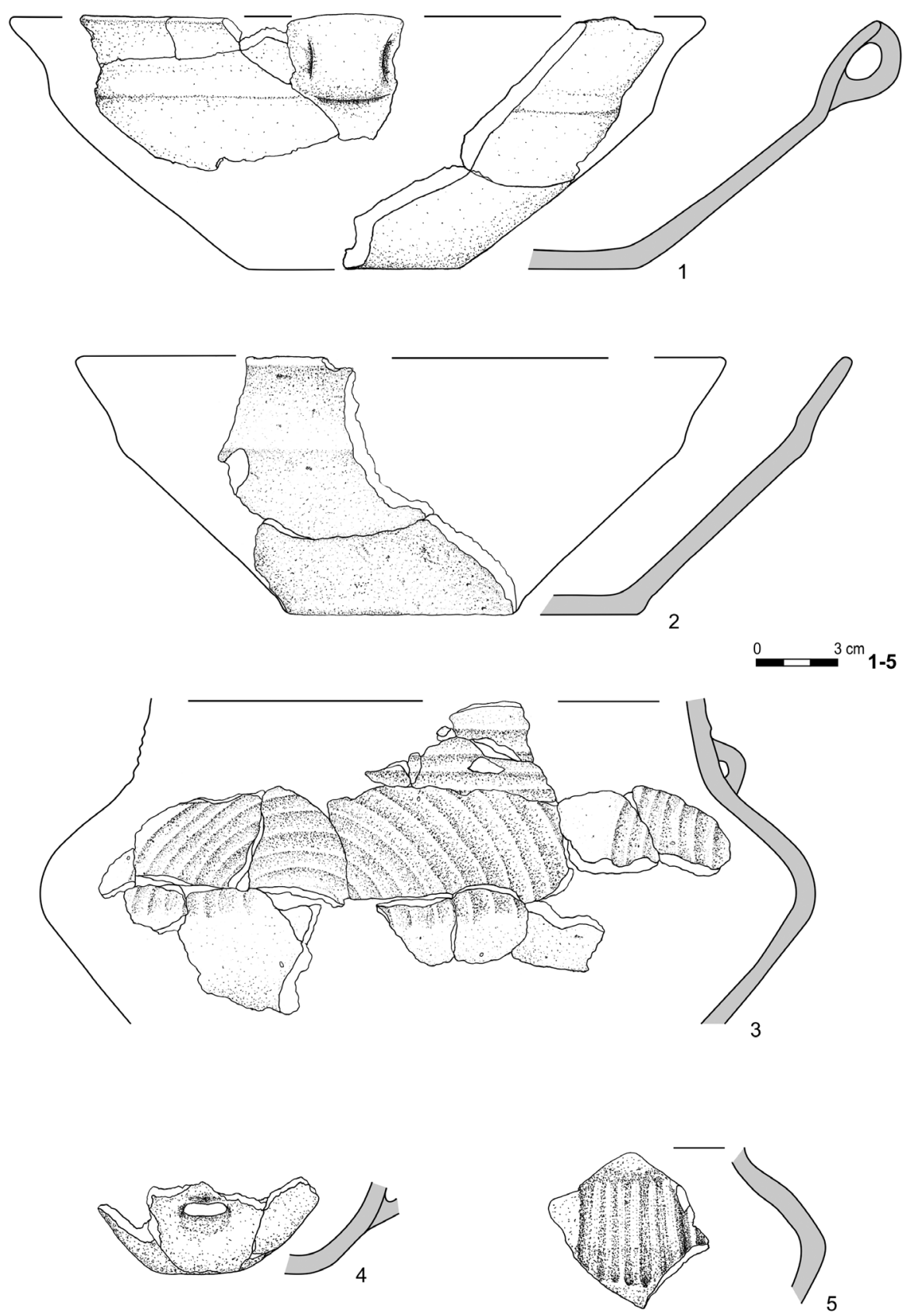

Fig. 4. Michałowice, Czarnocin commune, site. 1. Grave goods from features 119 (1), 121 (2), 118, 123 $(3,4)$ and 110 (5); (1-5) - clay. Drawn by P. Cyganiewicz, M. Okońska and J. Zagórska-Telega 
One has to consider a possibility that the shallow burials have been considerably disturbed or damaged, a situation also known from other sites linked with the Lusatian culture (Gedl 1992, 14; Zyzman 2009, 305-310; Konieczny 2014, 110-111). On the other hand, there are no grounds to believe these are remains of inhumation burials, since absolutely no uncremated skeletal elements have been found. It is worth recalling in this context that in the Michałowice cemetery uncremated bones from human and animal burials linked with the Trzciniec and Przeworsk cultures have survived very well (cf. Zagórska-Telega, Bulas, Pikulski, Szczepanek 2011; Zagórska-Telega, Pikulski, Szczepanek 2014).

It seems that the features discovered in season 2013 and associated with the Lusatian culture cemetery should be linked with phase Zofipole-Raciborsko, distinguished by M. Gedl and dated to Period IV (Gedl 1982, 23-24). This is suggested by both the Zofipole vase from feature 113 and the fluted vase from feature 118. The Zofipole-Raciborsko phase of Lusatian culture development is connected with the Kraków sub-group of the Lusatian culture's Silesian group, and marks a period when connections with Silesia were still strong in the Kraków region. ${ }^{4}$

The excavations of 2013 also revealed five features attributed to the Przeworsk culture (features 109, 110, 111, 112, and 116).

Of particular note is the first Przeworsk culture inhumation burial discovered in Michałowice site (feature 109). ${ }^{5}$ A regular, elongated grave cut around $190 \times 100 \mathrm{~cm}$, oriented along the NS axis, was identified at a depth of $30 \mathrm{~cm}$, immediately beneath the topsoil. The exploration revealed poorly preserved bones of a skeleton placed on the left side, with contracted legs and with the head to the $\mathrm{N}$ (Fig. 5). By the head of the deceased female (see the anthropological analysis) two ceramic vessels were found. The first one is a small, well-preserved vase with smooth, black surfaces (Fig. 5: 1), while the other one is a damaged, poorly fired bulbous vessel (Fig. 6: 1). A severely corroded iron artefact, probably a knife, was also found next to the vessels, and a bronze pin with a profiled head (Fig. 6: 2) was found to the right of the head of the deceased. On her shoulders the deceased had a pair of bronze eye brooches (Fig. 6: 3, 4), and another bronze brooch was found under one of the vessels behind the head (Fig. 5: 2). Furthermore, a bronze sewing needle was uncovered under the pelvis of the deceased (Fig. 5: 3).

The bronze pin terminating in a profiled head (Fig. 6: 2) is a unique find. The head has five protrusions along the perimeter and one round protrusion on the flaring head's top. A similar flaring element can be seen below the round head. It is worth noting that pins with heads of such form find no counterpart in Beckmann's classification (1966), and the only artefact akin to the pin in question comes from grave XX in the cemetery at Niecieplin, Dist. Garwolin (Kozłowska 1958, 348, pl. CXI: 9), although in this case the head has a double spherical protrusion on the top and the flaring element beneath the head is more ornamental, decorated with granulation. Grave XX also yielded a fragment of a bracelet made from a bronze bar, and a fragment of a pendant representing Stanek type IA, which in the source publication was erroneously described as a brooch fragment (Kozłowska 1958, 348, pl. CXI: 10; Stanek 1999, 332, 343, fig. 3: 9). Grave XX from Niecieplin can broadly be dated to the Early Roman period (cf. Andrzejowski 1994; 2001; Stanek 1999). Another pin discovered in feature 55 (grave 4/69) in the cemetery at Pajewo-Szwelice, Dist. Ciechanów (Dłubakowski 2005, 45, pl. XLVII/55: 8 ), is perhaps analogical. This is suggested by small protuberances on the pin's spherical head,

\footnotetext{
4 We would like to kindly thank A. Gawlik and E. Kolebuk for their valuable comments concerning the Lusatian culture features.

5 The feature has already been published before (Zagórska-Telega, Pikulski, Szczepanek 2014).
} 


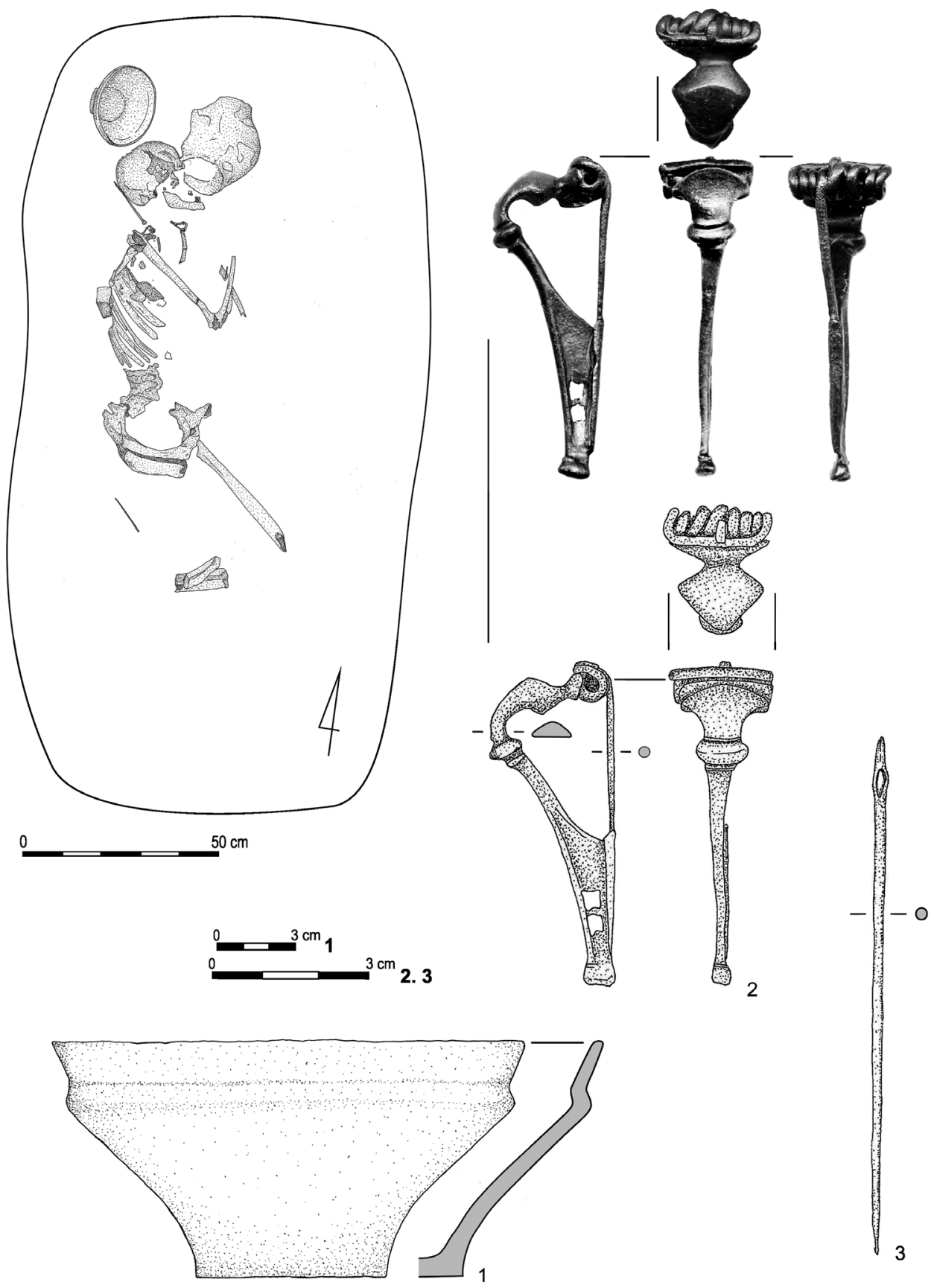

Fig. 5. Michałowice, Czarnocin commune, site. 1. Grave goods from feature 109; (1) - clay, (2, 3) bronze. Drawn by P. Cyganiewicz, M. Okońska and J. Zagórska-Telega 
mentioned in the description and featuring on the drawing. However, this specimen is badly damaged and corroded.

The brooches retrieved from feature 109 represent two different types. The pair placed on the shoulders of the deceased are eye brooches of type A.45 (Fig. 6: 3, 4), while the one found under one of the vessels is a A.67. Neither of these types are particularly frequent finds in the Przeworsk culture range (Jamka 1964, 36-52; Liana 1970, 442; 1976, 140; Kunow 1998, fig. 6; Dąbrowska 2003; Rudnicki 2006; Lipkowska 2008; Luczkiewicz 2010). Eye brooches of the A.45 type were popular above all in the lower Elbe basin and in Bohemia, and slightly less so on the lower Vistula (Kunow 1998, 106-119, fig. 6; Tuszyńska 1999, 369; Steidl 2013; Horník 2015). Their occurrence within the Przeworsk culture area is linked with the inflow of what is known as the Bohemian wave of imports (Wołąiewicz 1970, 218; Andrzejowski 1998, 54; Tuszyńska 1999, 369; Steidl 2013, 167). In Central European Barbaricum, brooches of this type date to phase B1 (Godłowski 1985, 41; Liana 1976, 140; Völling 1995, 233-235; Kunow 1998, 104-106; Droberjar 1999, 74).

The third brooch from grave 109 belongs to type A.67 (Fig. 5: 2), widely regarded as imports from Roman Provinces (Liana 1970, 441; Godłowski 1977, 10). The specimen in question belongs to short forms, which in Demetz's classification represent variant A.67b2 (Demetz 1999, 130), ${ }^{6}$ which means younger forms (A.67b), occurring both in phase B1a and B1b (Liana 1970, 441; 1976; cf. Droberjar 1999, 141). Along with brooches A.45 and A.236c, brooches of the A.67b type are among leading forms of T. Völling's horizon IV, which are synchronised with the late years of the reign of Augustus and above all with the reign of Tiberius (Völling 1995, 233-235; Kunow 1998, 104-106), and occurred primarily in what today is the Czech Republic and Slovakia (Demetz 1998, fig. 4; 1999, map 42; Dąbrowska 2003, 156).

Two ceramic vessels had been placed above the head of the deceased buried in grave 109 . The first one is a vase having smooth black surfaces, with a distinctly marked shoulder placed in the upper part of the vessel (Fig. 5: 1). Such forms belong to Liana type VI/1, and date primarily to phase B1 of the Early Roman period (Liana 1970, 439). The other vessel was very poorly fired and considerably damaged, but it can be classed as a bulbous vessel of Liana type I/1 (Fig. 6: 1). These forms are typical of the Younger Pre-Roman period and the beginnings of the Early Roman period (Liana 1970, 438-439).

On the basis of the artefacts presented above, grave 109 can be linked with phase B1 of the Early Roman period, more likely with its younger stadium known as phase B1b.

It should be noted that feature 109 described here is the first inhumation burial in the Michałowice cemetery. All the burials previously discovered in the site had been cremations, which was the typical form of body deposition in the Przeworsk culture area. However, inhumations incidentally occurred in Przeworsk culture necropolises, as single graves or small clusters, throughout the entire period when this cultural unit developed (cf. Szydłowski 1964; Godłowski 1981; Niewęgłowski 1981; Błażejewski 1998), and their appearance has been linked with influences from neighbouring areas. In the early stage, inhumation in the Przeworsk culture is believed to reflect the survival of older, Celtic traditions (cf. Potocki, Woźniak 1959, 92; Godłowski 1969, 113; 1981, 109; Bykowski 1976, 152-154; Niewęgłowski 1981, 54-55; Dąbrowska 1988, 143-145; Błażejewski 1998, 23; Margos 2000, 255 - with older literature;

6 In this context we are inclined to accept the view expressed by M. Mączyńska positing that it is difficult to distinguish between late forms of A.67 and A.68 brooches based on the shape of the apertures on their feet, and that in some cases it is more reasonable to speak about brooches A.67-68 (Mączyńska 2001, cf. also Pieta 1982, 41). 

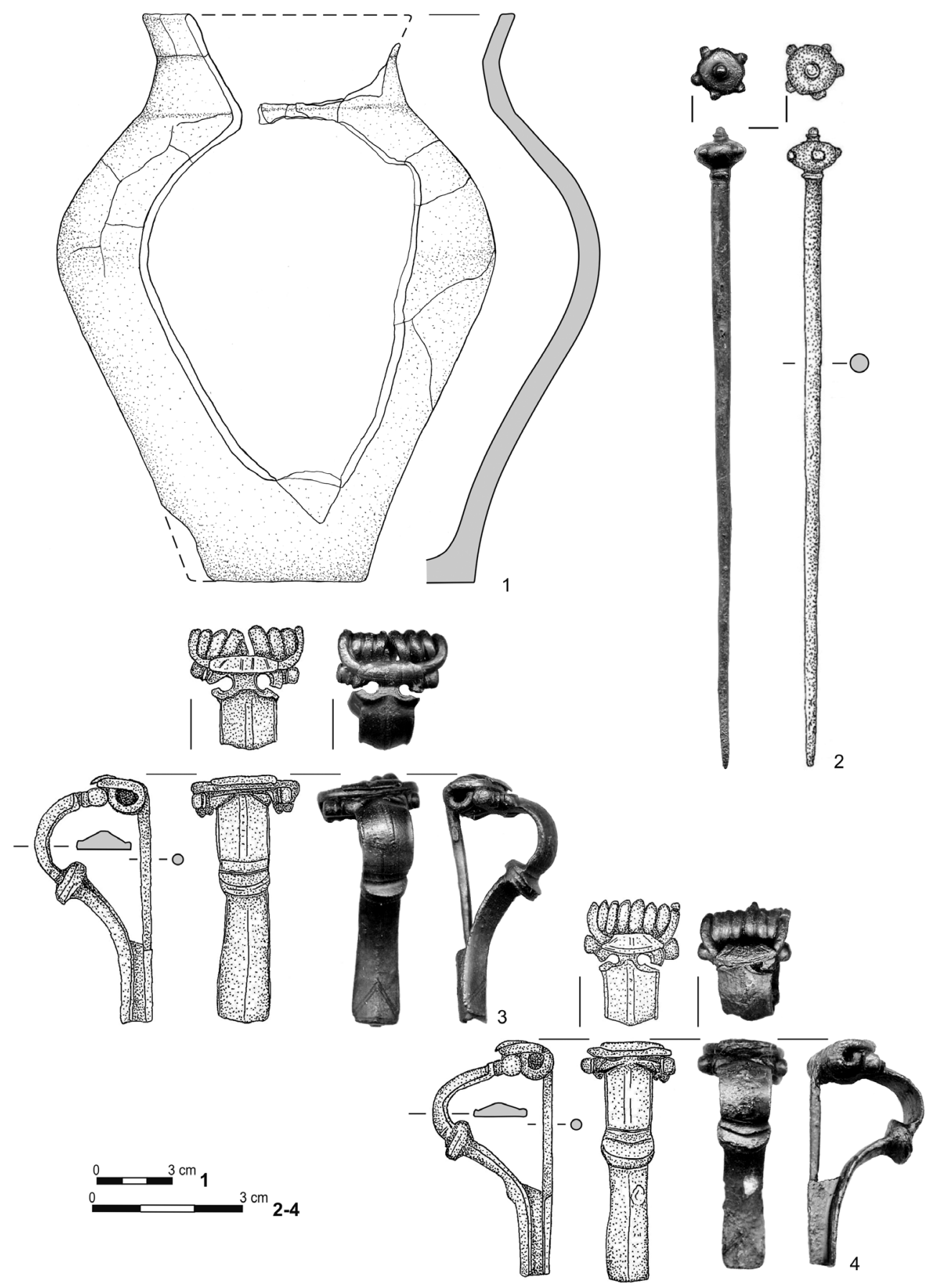

Fig. 6. Michałowice, Czarnocin commune, site. 1. Grave goods from feature 109; (1) - clay, (2-4) bronze. Drawn by P. Cyganiewicz, M. Okońska and J. Zagórska-Telega 


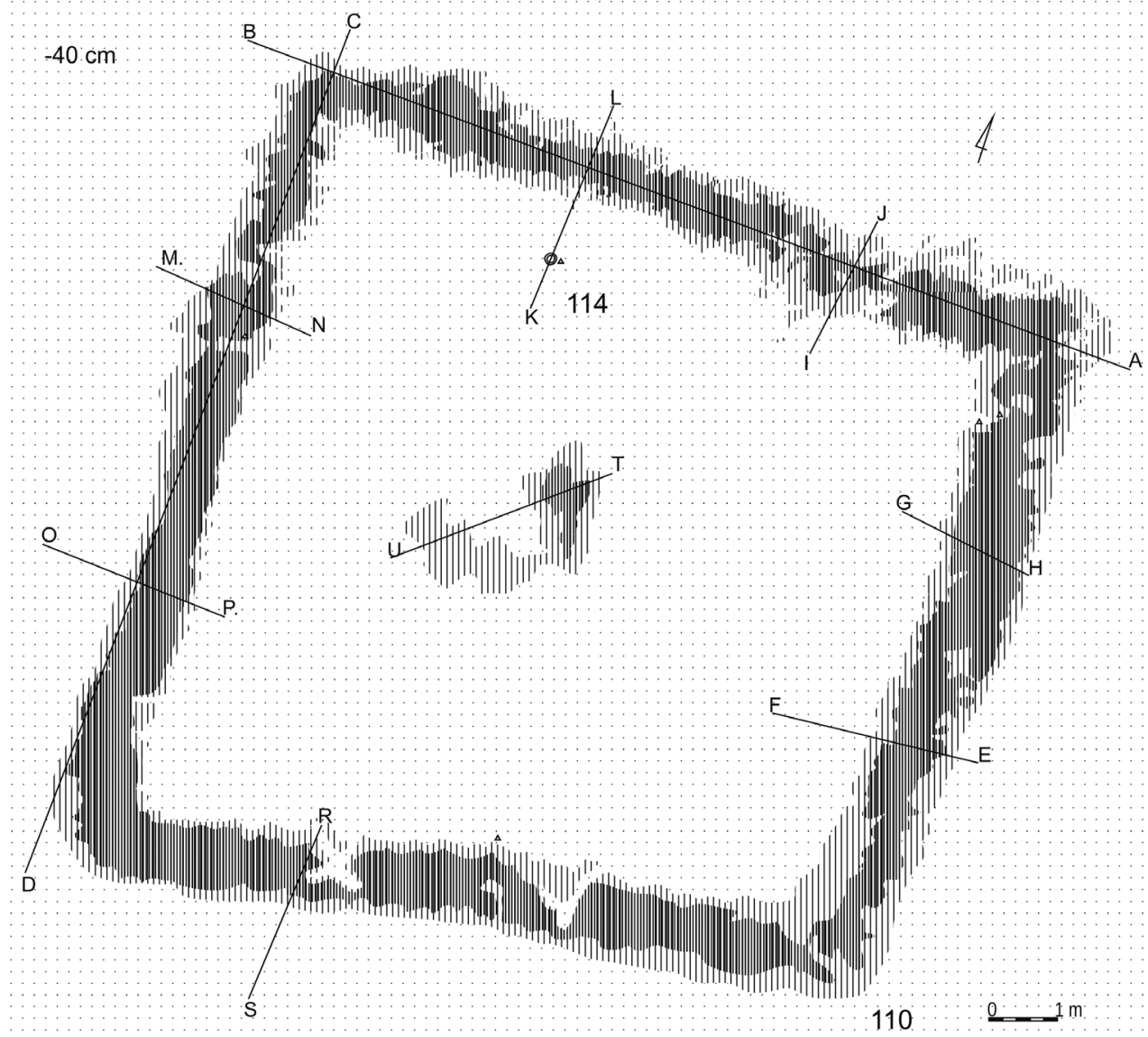

A _ - rom

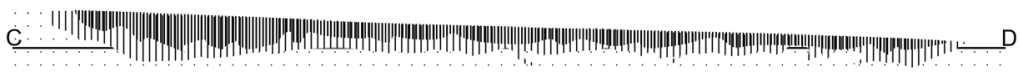

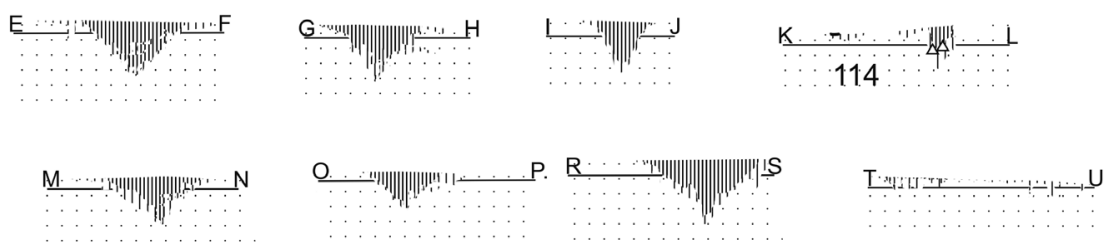

Fig. 7. Michałowice, Czarnocin commune, site. 1. Feature 110. Drawn by J. Zagórska-Telega 

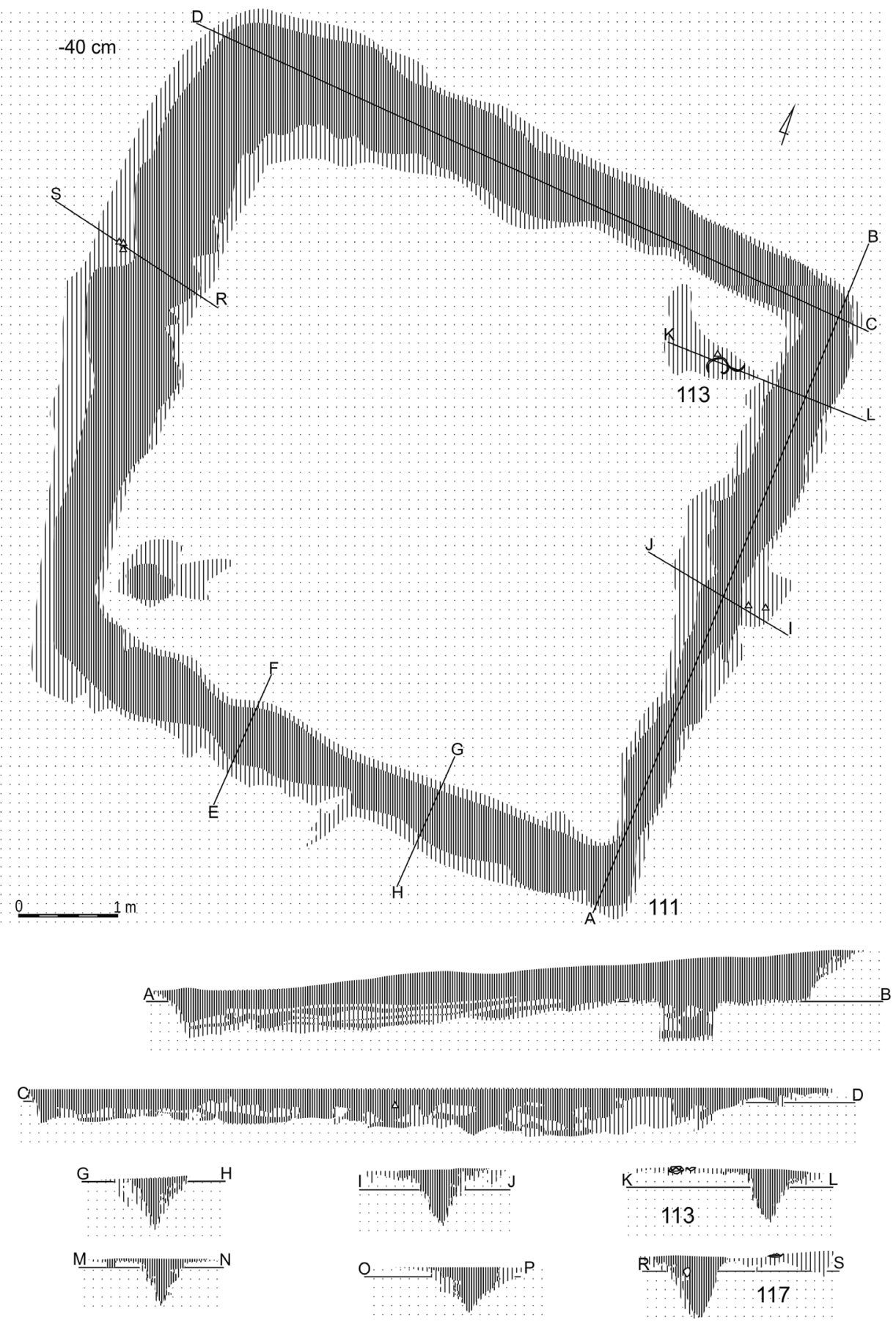

Fig. 8. Michałowice, Czarnocin commune, site. 1. Feature 111. Drawn by J. Zagórska-Telega 
Lemaniak 2006). In the Early Roman period, apart from the earlier concentrations known from Silesia, eastern Wielkopolska and Kujavia (cf. Bykowski 1976; Kokowski 1989, 65-124; 1992; Ibragimow 2011), and from the so-called Nidzica group in north-eastern Mazowsze (Okulicz 1965), inhumation burials started to appear in other areas within the Przeworsk culture range. Among other places, they are known from Małopolska: from Kraków-Mogiła; Kawczyce, Dist. Busko Zdrój; Marzęcin, Dist. Pińczów; and Szarbia, Dist. Proszowice (Hachulska-Ledwos 1966; Kaczanowski, Poleski 1985; 1990; Naglik 2001), as well as Trześnia, Dist. Tarnobrzeg; and Rosiejów, Dist. Pińczów (Demetrykiewicz 1897, 155-156; Wawrzeniecki 1908, 72-75; Jamka 1966, 155-157). ${ }^{7}$

It has already been suggested in the subject literature that the phenomenon of inhumation may have spread via "Marcomannic" Bohemia in the period when the kingdom of Maroboddus existed (Margos 2000 - with older literature). These influences allegedly flowed from the upper Elbe basin or, by intermediary of this area, from Roman Provinces, and the very appearance of the inhumation rite in Central European Barbaricum was due to the adoption of certain beliefs from the Celts from Pannonia (Wołągiewicz 1981, 151; Błażejewski 1998, 168, 172) or Raetia (Lichardus 1984, 59) in a period parallel with the spread of strongly profiled pottery style. Recently, other hypotheses have been proposed in the literature, positing that the spread of inhumation in the Przeworsk culture may have had its sources in the Bohemian Basin, in Pomerania, or even in the Sarmatian milieu (Bednarczyk, Łaszkiewicz 1990, 53-54). It has also been noted that the appearance of the inhumation burial rite in the Baltic Sea basin, for example in the Oksywie culture cemeteries, pre-dated the strongly profiled ceramic style (Margos 2000, 260 ), which allegedly proves a northern genesis of the custom in question. The inhumation burial discovered at Michałowice seems to confirm the "Marcomannic" genesis of inhumation in Małopolska, and this direction is also corroborated by the brooches of types A.45 and A.67 found in grave 109, which are considered as objects typical of Bohemia in the beginnings of the Early Roman period (cf. Cosack 1979, 62). Moreover, it is worth emphasising that, as has already been signalled in the literature, in Małopolska and Upper Silesia inhumation burials in Przeworsk culture cemeteries co-occur with groove features, the latter being commonly linked with Celtic traditions (Kaczanowski, Poleski 1985, 130).

As mentioned, the excavations carried out in 2013 also revealed three more groove features linked with the Przeworsk culture cemetery (features 110, 111, and 112). They were all rectangular in shape and were oriented according to the cardinal directions. The largest one (110) was approx. $1250 \times 1250 \mathrm{~cm}$ (Fig. 7), and it is worth emphasising that it belongs among the largest such features discovered at Michałowice, and at the same time is one of the largest groove features known from Przeworsk culture sites in general. At the level of its discovery, immediately after the removal of the topsoil, the groove's arms were from 80 to $100 \mathrm{~cm}$ wide. The fill was intensively brown soil with no clear traces of stratification. All the transversal cross-sections cutting the groove were in the shape of an elongated, regular triangle. The arms'

\footnotetext{
7 In Małopolska there also are inhumation burials dated to the beginnings of the Younger Roman period, known from such sites as Zawada, Dist. Staszów, Ciuślice, Dist. Kazimierza Wielka, and Kryspinów, Dist. Kraków (Gajewski 1974; Godłowski 1974, 43; Chomentowska 1980; Chomentowska, Michalski 1987). Roughly at the same time, single inhumations also appear in cemeteries in Wielkopolska and in central Poland, e.g. in Wymysłowo, Dist. Gostynin, and Konin and Młodzikowo, Dist. Środa Wielkopolska (Kostrzewski 1947, 196-197; Jasnosz 1952, 16, 45, fig. 18, 53; Dymaczewski 1958, 356). It has been suggested that new foci of inhumation may have emerged in the Roman Period under the influence from the Wielbark culture (Chomentowska, Michalski 1987, 199) and from the northern part of the Elbe Germanic complex (Niewęgłowski 1981, 78).
} 
bottoms reached a depth of maximum 110-120 cm beneath the ground surface. The fill contained single, dispersed potsherds, very tiny pieces of cremated bone (with one concentration recorded in the central part of the $\mathrm{N}$ arm of the groove), and tiny charcoals. At the very bottom of arm N some small, darker stains roughly $10 \mathrm{~cm}$ in diameter were recorded, possibly traces of stakes driven into the feature's bottom. It is worth mentioning here that such traces have not been recorded so far in any other feature at Michałowice.

In the area surrounded by the arms of feature 110, many darker spots and irregular stains were recorded, which occurred at shallow depth, immediately beneath the topsoil. They included cluster 8 and features 108,114,118, and 123, which were the remains of damaged features linked with the Lusatian culture. The fill of the feature also contained fragments of pottery and tiny bronze objects, remains of grave goods. On the other hand, no features associated with the Przeworsk culture cemetery were found in the area enclosed by the arms of feature 110 .

Two smaller groove features (111 and 112) were both approx. $800 \times 800 \mathrm{~cm}$ in size (Fig. 8). Feature 111 was easily detectable against the loess bedrock due to the intense colour of its fill, and its arms were from 60 to $80 \mathrm{~cm}$ wide. The fill was dark-brown soil, clearly stratified, and it contained small amounts of archaeological material in the form of tiny potsherds and cremated human bones. The depth of the groove's arms reached 80-90 cm beneath the ground surface in the deepest places. A few darker spots were recorded in the immediate vicinity of feature 111, probably being remains of damaged sepulchral features associated with the Lusatian culture (features 113, 117, 119, and 121 - see above).

Feature 112 was less regular in shape. It was also approx. $800 \times 800 \mathrm{~cm}$ in size, but the $\mathrm{N}$ arm was shorter, only $700 \mathrm{~m}$. At the level of the discovery, the arms were $70-80 \mathrm{~cm}$ wide. The fill was homogeneous soil of light-brown colour, slightly blurred in the lower parts. It contained single, dispersed potsherds, tiny fragments of cremated bone without any distinct concentrations, and charcoal. In cross-sections the feature was poorly legible, had a trough-like shape, and its depth reached $90 \mathrm{~cm}$ beneath the ground surface at maximum. In the central part of the southern arm, remains of a badly damaged cremation burial were identified (feature 116), most likely secondarily dug into the groove's arm. Feature 116 contained a great number of highly burnt potsherds originating from several vessels, and a considerable amount of cremated human bone. Also found in this feature were fragments of what was probably an A.IV brooch, numerous lumps of melted bronze, and fragments of bronze and iron artefacts. A bronze pin discovered above the cluster of pottery and bones most likely also connects with this feature. The discovered artefacts, which included among others elements of weaponry, suggest this was a male burial, which has also been confirmed by the anthropological analysis (see below).

The groove features presented above yielded only few, tiny, and uncharacteristic fragments of pottery, which makes it impossible to determine the time when they were in use. More light on this issue can be shed by the analysis of their spatial relationship to other features, first of all to well-furnished graves. The arrangement of the groove features discovered thus far in the Michałowice cemetery seems to suggest that they were all established and used roughly at the same time, or in only small chronological distance. It needs to be emphasised that none of the groove features cut into another groove feature, nor into any of the Przeworsk culture graves, which allows for a conclusion that the groove features are generally older than the individual burials. All the groove features are precisely oriented along the cardinal directions, and form distinct rows. It is also worth noting that the largest two features (90 and 110) are situated at the opposite ends of the cemetery, in the NE and SW. Naturally, the recorded arrangement may be coincidental and stem from the fact that the cemetery has been significantly damaged (e.g. the NW part is under present-day buildings). Nevertheless, the location of two other features: 
inhumation grave 109 presented above and symbolic partial burial 78, is also interesting (cf. Zagórska-Telega, Pikulski, Szczepanek 2014; Zagórska-Telega 2018). Both these features fit perfectly into the spatial arrangement of the site, are oriented along the cardinal directions (exactly as the groove features), and were found in-between groove features. The elongated shape of feature 55 may have possibly also been determined by the close proximity to inhumation grave 109. It seems justified to propose that groove feature 55 was intentionally "aligned" to the place where it was established, so that it would not damage feature 109. Artefacts retrieved from features 78 and 109, which included brooches A.45 and A.67 (feature 109) and A.68 (feature 78) allow these features to be dated to developed phase B1 (B1b) of the Early Roman period (cf. Zagórska-Telega, Pikulski, Szczepanek 2014; Zagórska-Telega 2018). Therefore, the time when the groove features from Michałowice were used should be determined as the same period, or slightly earlier.

On the other hand, despite the discovery in 2013 of new groove features in the Michałowice cemetery, the genesis and function of such features still remain unexplained (cf. Pikulski, Zagórska-Telega 2011; Zagórska-Telega, Pikulski 2014 - with older literature).

\section{Natural features}

The excavations conducted in 2014 did not reveal any archaeological features, only single fragments of pottery and bone, and metal objects were found. Among uncontexted artefacts recovered from the investigated area were small iron fittings, a bucket-shaped pendant, and a fragment of a pin, possibly from a brooch. However, it cannot be determined whether these objects originally belonged to damaged Lusatian culture and Przeworsk culture features possibly once existing in this place, or were redeposited there by ploughing from some other place.

Among the results of season 2014, the discovery of two features interpreted as natural features merits attention and discussion. The first one was discovered in the NE part of the explored area. After removing the topsoil, a round, dark-brown area of subsoil was recorded, whose colour and consistence were different than the topsoil layer. The exploration of successive arbitrary layers from a depth of $30 \mathrm{~cm}$ to approx. $50 \mathrm{~cm}$ revealed soil which in terms of colour and consistence resembled a so-called buried humus layer, which was already identified at Michałowice in preceding seasons - among other places, in a natural closed depression (Zagórska-Telega, Pikulski, Szczepanek 2015, 158-161). It is worth mentioning that the diameter of the feature diminished systematically with each explored level, reaching $1000 \mathrm{~cm}$ at a depth of $50 \mathrm{~cm}$. In a provisional northern cross-section, which has not been documented, the feature resembled a trough in shape. The northern part of the feature was left unexplored for possible geomorphological research in future.

In addition, a decision was made in 2014 to excavate a fragment of a filled-back loess ravine, a part of which, as shown by geomagnetic prospection, was within the opened trench. ${ }^{8}$ Such features are common in loess areas and have already been described in detail in the subject literature (cf. Jahn 1950; Gilewska 1959; Kruk 1971; Brodzikowski, Van Loon 1991; Kościelniak 2003).

8 The geomagnetic survey was part of a broader research program carried out by Piotr Wroniecki, at Michałowice site 1, among other places (cf. Wroniecki 2012). Previously, geophysical surveys were also performed at Michałowice by the teams led by Łukasz Porzuczek and Marcin M. Przybyła. 
In light of the results of surveys using non-invasive methods, the ravine in question follows through the entire $\mathrm{W}$ part of the site, along the N-S axis. Therefore, the aim of the excavation was to gather data concerning its characteristics, and possibly determine the moment when it ceased to function, in the context of the nearby cemeteries dated to the Bronze and Iron Ages. After removing the topsoil, a homogeneous dark layer with no detectable boundaries was recorded at a depth of $30 \mathrm{~cm}$ in the E part of the main trench. It was only at a depth of $70-80 \mathrm{~cm}$ that the outlines of an elongated structure running N-S were identified. At this depth, the structure had irregular and in places blurred boundaries, and its width counted $\mathrm{W}$ to E could be estimated as approx. $500 \mathrm{~cm}$. At the later stages of exploration, when the bottom part of the structure was identified at a depth of $110 \mathrm{~cm}$, two poorly detectable grooves were recorded in the structure's central part, which also followed the N-S line. These grooves seem to be traces of ruts left by wheeled vehicles, perhaps horse-driven carts. Such rut traces are known from other places in loess uplands (Kruk 1971, 266). The shape of the structure recorded in the N wall of the trench resembled a trough, and the fill was clearly heterogenous and stratified. The total depth of the structure calculated from the ground surface was approx. $160 \mathrm{~cm}$.

At the present stage of research it is very difficult to attempt dating the discussed structure. Its exploration revealed sparse fragments of various kind of artefacts. As for the fill, the upper part in particular, it seems probable that it formed as a result of destruction of top deposits in the site, in which shallow burials may have been placed. Soil from this area could have filled the ravine when the site was levelled. Therefore, the apparent lack of archaeological features may be a picture distorted by complex soil processes occurring in this part of the site in the past. The discovery in the ravine's fill of single artefacts originating from the Roman period may be indicative of Roman period burials in the vicinity. Perhaps these artefacts originate from another part of the site, more to the $\mathrm{N}$ from the investigated area, which is now under buildings belonging to a nearby farmstead, and they could have found their way to the ravine due to slope processes.

Uncovered in 2014, the area devoid of archaeological features can be interpreted in two ways: as proof for reaching the NW boundary of the site, or as an area left unused while the sepulchral activity was shifted further, to a part of the site where loess ravines did not interfere with establishing the burials.

\section{Anthropological analysis}

The anthropological analysis followed the methodology proper for inhumation (White, Folkens 2005) and cremation (Fairgrieve 2008) burials. This report encompasses the materials from graves attributed to the Lusatian and Przeworsk cultures.

\section{Lusatian culture}

Cremated bones from four Lusatian culture features have survived. Due to considerable damage and small amounts of bone, which could have got into the features accidentally, it is difficult to determine whether all four features were cremation burials. Only in feature 118 was a slightly greater amount of bone found $-16 \mathrm{~g}$. However, the good preservation of uncremated bones in Trzciniec and Przeworsk culture graves suggests that at least single skeletal elements, e.g. tooth enamel, should have survived. 
Feature 108

Bones strongly and evenly charred, of crème colour.

Bone weight: $0.2 \mathrm{~g}$

Very tiny fragment of a long bone shaft survived, belonging to an individual of undetermined age and sex.

Feature 118

Bones strongly and evenly charred, of crème colour.

Bone weight: $16 \mathrm{~g}$

Very tiny fragments of delicate bones from the skullcap and long bone shafts of a child aged Infans I, of undetermined sex.

Feature 119

Bones strongly and evenly charred, of crème colour.

Bone weight: $0.5 \mathrm{~g}$

Very tiny fragments of long bone shafts, belonging to an individual of undetermined age and sex.

\section{Feature 121}

Bones strongly and evenly charred, of crème colour.

Bone weight: $6 \mathrm{~g}$

Very tiny fragments of long bone shafts, belonging to an adult individual of undetermined sex.

\section{Przeworsk culture}

The analysed anthropological remains originated from one inhumation grave, one cremation grave dug into a groove feature, and three groove features.

Feature 109 - inhumation burial

The skeleton is very poorly preserved. The surviving elements include the following: a delicate, secondarily damaged cranial vault with partially obliterated sutures; a small right mastoid process; squamous part of occipital bone with poorly expressed nuchal lines; right part of a delicate mandible. Permanent teeth with heavily attrition were preserved: right and left P1 and P2 from the mandible, and P2, M1, and M3 from the right maxilla. The postcranial skeleton is represented by articular processes of cervical vertebrae, fragments of shafts of two lumbar vertebrae, and fragments of right and left ribs. Elements of upper limbs included the shaft of the right clavicle with the sternal and acromial ends damaged, left clavicle with the sternal end damaged, fragments of the left and right scapulas, and left coracoidal process. There also is the diaphysis of the right humerus with both the proximal and distal epiphyses damaged, diaphysis from the radius and right ulna with damaged epiphyses, and a fragment of diaphysis from the left radius. The deltoid tuberosity on the diaphysis of the surviving, right humerus is relatively well-developed. The lower limbs are represented by fragments of right and left hip bones with wide greater sciatic notch, the diaphysis of the left femur with epiphyses damaged, a fragment of the diaphysis of the right femur with the proximal epiphysis damaged, and fragments of diaphyses of tibiae and fibulae. The linea aspera is moderately marked on the diaphyses of the femoral bones. 
The preserved elements of the skeleton allowed the age at death of the deceased to be established as approx. 40 years (Maturus). The dimorphic traits point to a female. The maximum length of the humerus measured in situ allowed the intravital body height to be estimated as around $150 \mathrm{~cm}$ (using Pearson 1899).

In addition, fragments of strongly charred shafts of long bones belonging to an adult were found in the northern part of the feature. They most likely did not belong to the analysed remains, have found their way to the grave by accident.

Feature 116 - cremation burial

Bones strongly and evenly charred, of crème colour.

Bone weight: $320 \mathrm{~g}$

Massive fragments of the skullcap with partially obliterated sutures, fragments of roots of permanent teeth, and fragments of shafts and epiphyses of long bones. The surviving elements allowed for a conclusion that the bones belonged to a male approx. 40-50 years of age (Maturus).

Groove feature 110

Bones strongly and evenly charred, of crème colour.

Bone weight: $175.7 \mathrm{~g}$

Tiny fragments of the skullcap, fragment of a root of a permanent molar, and fragments of shafts and epiphyses of long bones. The surviving elements allowed for a conclusion that the bones belonged to an adult individual of undetermined sex. The massiveness of some of the long bone shafts points to a male.

Groove feature 111

Bones strongly and evenly charred, of crème colour.

Bone weight: $26.5 \mathrm{~g}$

Tiny fragments of skullcap bones, and very tiny fragments of shafts and epiphyses of long bones. The surviving elements allowed for a conclusion that the bones belonged to an adult individual of undetermined sex.

Groove feature 112

Bones strongly and evenly charred, of crème colour.

Bone weight: $12.7 \mathrm{~g}$

Very tiny fragments of shafts and epiphyses of long bones. The surviving elements allowed for a conclusion that the bones most likely belonged to an adult individual of undetermined sex.

The groove features contained varying amounts of typically highly dispersed bone. Apart from dispersed bone fragments, in the best preserved feature, 110, one larger concentration of bones was identified in the central part of the $\mathrm{N}$ arm. The anthropological conclusions concerning bone materials from the groove features were based on the determinations of the smallest possible number of individuals buried there, assessed by the observation of diagnostic elements. In all these features bones were highly fragmented and there were no bone elements identified that could allow for distinguishing remains belonging to different individuals. However, this lack of anthropological grounds cannot be seen as conclusive in this context, since one has to assume that some of the bones entered the groove features accidentally, having originally belonged to damaged graves or being reflections of some undetermined funeral practices. 


\section{Conclusions}

The research carried out in seasons 2013 and 2014 encompassed an area of 10 ares and resulted in the discovery of 16 archaeological features and two natural structures.

The majority of the archaeological features are very badly damaged cremation burials linked with the Lusatian culture population. They should be linked with the Kraków sub-group of the Silesian group of the Lusatian culture, and in terms of chronology with phase ZofipoleRaciborsko dated to Bronze Age Period IV. Moreover, other groove features were discovered in the Michałowice site, as well as a cremation burial dug into one of the grooves, all of them linked with the Przeworsk culture cemetery. As well, an inhumation burial associated with the Przeworsk culture was found, the first such feature in the cemetery. All the mentioned features should be dated to phase B1 of the Early Roman period.

The excavations of 2014 perhaps revealed the NE boundary of the site, both of the Lusatian and Przeworsk cultures' cemeteries, as no archaeological features associated with these cultural units were recorded. At the same time, however, single artefacts were found which may point to a considerable amount of damage to this part of the site.

The works are planned to be continued in subsequent seasons.

\section{Badania archeologiczne na wielokulturowym stanowisku 1 w Michałowicach, gmina}

\section{Czarnocin, w sezonie 2013-2014}

Badania wykopaliskowe na wielokulturowym stanowisku $1 \mathrm{w}$ Michałowicac są kontynuacją prac prowadzonych od roku 2008. Do dnia dzisiejszego odsłonięto obszar o łącznej powierzchni około 40 arów i odkryto przy tym 122 obiekty archeologiczne. W sezonach 2013-2014 przebadano łącznie teren o powierzchni 10 arów. W trakcie badań odkryto ciałopalne obiekty związane z kulturą łużycką i przeworską, a także pierwszy na cmentarzysku pochówek szkieletowy oraz kolejne obiekty rowkowe związane z kulturą przeworską.

\section{References}

Andrzejowski J., 1994 Powiąania kultury przeworskiej $i$ wielbarskiej w świetle znalezisk bransolet, (in:) J. Gurba, A. Kokowski (eds.), Kultura przeworska, I, Lublin, Lubelskie Materiały Archeologiczne, 7/1, pp. 317-341.

1998 Nadkole 2. A Cemetery of the Przeworsk Culture in Eastern Poland, Monumenta Archaeologica Barbarica, 5, Kraków.

2001 Wschodnia strefa kultury przeworskiej - próba definicji, Wiadomości Archeologiczne, 54 (19951998), pp. 59-87.

Bajda-Wesołowska A., Bochnak T., Hozer M., 2014 Bogaty grób kobiecy z wczesnej epoki żelaza odkryty w miejscowości Zabłotce, pow. jarosławski, stan. 27, Materiały i Sprawozdania Rzeszowskiego Ośrodka Archeologicznego, 35, pp. 105-125.

Beckmann B., 1966 Studien über die Metallnadeln der römischen Kaiserzeit im freien Germanien, Saalburg Jahrbuch, 23, pp. 5-100. 
Bednarczyk J., Laszkiewicz T., 1990 Cmentarzysko z okresu wpływów rzymskich w InowrocławiuSzymborzu, woj. bydgoskie, stanowisko 1, Inowrocław.

Błażejewski A., 1998 Obrządek pogrzebowy kultury przeworskiej na Śląsku, Wrocław.

Brodzikowski K., Van Loon A.J., 1991 Glacigenic sediments, Developments in Sedimentology, 49, pp. 1-674.

Bykowski K., 1976 Uwagi o szkieletowym obrządku pogrzebowym ludności kultury przeworskiej w okresie późnolateńskim i wczesnorzymskim, Acta Universitatis Wratislaviensis, Studia Archeologiczne, 7, pp. 139-163.

Chomentowska B., 1980 Cmentarzysko z okresu rzymskiego w Zawadzie, gm. Połaniec, woj. tarnobrzeskie, Wiadomości Archeologiczne, 45/2, pp. 225-236.

Chomentowska B., Michalski J., 1987 Grób szkieletowy z cmentarzyska rzymskiego w Zawadzie, gm. Połaniec, woj. Tarnobrzeg, Sprawozdania Archeologiczne, 39, pp. 193-200.

Cosack E., 1979 Die Fibeln der älteren Römischen Kaiserzeit in der Germania libera (Dänemark, DDR, BRD, Niederlande, CSSR): Eine technologisch-archäologische Analyse, Göttinger Schriften zur Vor- und Frühgeschichte, 19, Neumünster.

Dąbrowska T., 1988 Wczesne fazy kultury przeworskiej. Chronologia, zasięg, powiąania, Warszawa. 2003 Jeszcze raz o najwcześniejszych wpływach rzymskich na ziemiach polskich, (in:) A. Bursche, R. Ciołek (eds.), Antyk i barbarzyńcy. Księga dedykowana profesorowi Jerzemu Kolendo w siedemdziesiątą rocznicę urodzin, Warszawa, pp. 153-160.

Demetrykiewicz W., 1897 Cmentarzyska i osady przedhistoryczne w okolicy Tarnobrzega i Rozwadowa nad Sanem, Materiały Antropologiczno-Archeologiczne i Etnograficzne, 2, pp. 135-156.

Demetz S., 1998 Almgren Gruppe IV, Fig. 65-67: Zum Beginn der kräftig profilierten Fibel, (in:) J. Kunow (ed.), 100 Jahre Fibelformen nach Oscar Almgren, Wünsdorf, pp. 137-148.

1999 Fibeln der spätlatène- und frühen römischen Kaiserzeit in den Alpenländern, Frühgeschichtliche und Provinzialrömische Archäologie Materialien und Forschungen, 4, Rahden/Westf.

Dłubakowski, Z., 2005 Stanowisko wielokulturowe w miejscowości Pajewo-Szwelice, woj. mazowieckie, Warszawskie Materiały Archeologiczne, 9, pp. 9-218.

Droberjar E., 1999 Dobřichov-Pičhora. Ein Brandgräberfeld der älteren römischen Kaiserzeit in Böhmen (Ein Beitrag zur Kenntnis der Marbod-Reichs), Fontes Archaeologici Pragenses, 23, Pragae.

Durczewski Z., 1946 Grupa górnośląsko-małopolska kultury tużyckiej w Polsce, część I (syntetyczna), Prace Prehistoryczne, 4, Kraków.

1948 Grupa górnoślasko-małopolska kultury tużyckiej w Polsce, część II (materiały), Prace Prehistoryczne, 6, Kraków.

Dymaczewski A., 1958 Cmentarzysko z okresu rzymskiego w Młodzikowie pow. Środa, Fontes Archaeologici Posnanienses, 8-9, pp. 179-442. 
Fairgrieve S.I., 2008 Forensic Cremation, Recovery and Analysis, London - New York.

Fraś J., Reguła K., 2003 Badania archeologiczne prowadzone przez Muzeum Żup Krakowskich Wieliczka w latach 2001-2002, Studia i Materiały do Dziejów Żup Solnych w Polsce, 23, pp. 225-244.

Gajewski L., 1974 Odkrycia $i$ wykopaliska archeologiczne w Ciuślicach, pow. Kazimierza Wielka, Sprawozdania Archeologiczne, 26, pp. 73-90.

Gedl M., 1962 Kultura łużycka na Górnym Ślasku, Prace Komisji Archeologicznej, 3, Wrocław Warszawa - Kraków.

1979 Stufengliederung und Chronologie des Gräberfeldes der Lausitzer Kultur in Kietrz, Zeszyty Naukowe Uniwersytetu Jagiellońskiego, Prace Archeologiczne, 26, Kraków.

1982 Periodyzacja i chronologia kultury łużyckiej w zachodniej Małopolsce, (in:) M. Gedl (ed.), Południowa strefa kultury łużyckiej i powiązania tej kultury z południem, Kraków - Przemyśl, pp. 11-33.

1984 Wczesnołużyckie groby z konstrukcjami drewnianymi, Prace Komisji Archeologicznej, 22, Wrocław - Warszawa - Kraków - Gdańsk - Łódź.

1987 Cmentarzysko ze schytku epoki brązu w Kietrzu. Tom II, Wrocław - Warszawa - Kraków - Gdańsk - Łódź.

1989 Groby z młodszego okresu epoki brązu na cmentarzysku w Kietrzu, Kraków.

1991 Wczesnotużyckie cmentarzysko w Kietrzu. Czesść I, Kraków.

1992 Wczesnolużyckie cmentarzysko w Kietrzu. Część II, Kraków.

Gilewska S., 1958 Rozwój geomorfologiczny wschodniej części Wyżyny Miechowskiej, Prace Geograficzne, 13, Warszawa.

Godłowski K., 1969 Kultura przeworska na Górnym Ślasku, Katowice - Kraków.

1974 Kryspinów, district of Kraków (A cemetery from the end of Late La Tène and the Roman period), Recherches Archéologiques de 1973, pp. 27-35.

1977 Materiały do poznania kultury przeworskiej na Górnym Ślasku, część II, Materiały Starożytne i Wczesnośredniowieczne, 4, pp. 7-238.

1981 Kultura przeworska, (in:) J. Wielowiejski (ed.), Prahistoria Ziem Polskich, 5, Późny okres lateński i okres rzymski, Wrocław - Warszawa - Kraków - Gdańsk, pp. 57-135.

1985 Przemiany kulturowe $i$ osadnicze $w$ poludniowej $i$ środkowej Polsce $w$ młodszym okresie przedrzymskim $i$ w okresie rzymskim, Wrocław - Warszawa - Kraków - Gdańsk - Łódź.

Górski J., 2014 Kompleks osadniczy w Targowisku na tle osadnictwa kultury łużyckiej w zachodniej Małopolsce. Podsumowanie badań interdyscyplinarnych, (in:) J. Górski (ed.), Kompleks osadniczy kultury łużyckiej w Targowisku, stan. 10-12, pow. wielicki, Via Archaeologica. Źródła z badań wykopaliskowych na trasie autostrady A4 w Małopolsce, Kraków, pp. 213-220.

2018 Podkrakowska enklawa wczesnej kultury tużyckiej w świetle wyników najnowszych badań terenowych na trasie autostrady A4, Śląskie Sprawozdania Archeologiczne, 60/1, pp. 41-61.

Hachulska-Ledwos R., 1966 Grób szkieletowy z okresu wplywów rzymskich odkryty koło Kopca Wandy (Kraków-Nowa Huta), Materiały Archeologiczne, 7, pp. 151-154.

Horník P., 2015 Spony s očky na Královéhradecku. Eye-fibulae in the Hradec Králové region, Archeologie východních Čech, 9, pp. 140-154. 
Ibragimow K., 2011 Szkieletowy obrzadek pogrzebowy kultury przeworskiej na Dolnym Ślasku we wczesnym okresie rzymskim, (in:) E. Droberjar (ed.), Archeologie Barbarů 2010: Hroby a pohřebiště Germánů mezi Labem a Dunajem, Sborník př́spěvků ze VI. Protohistorické konferencje Hradec Králové, 6.-9. září 2010, Olomouc, pp. 163-182

Jahn A., 1950 Less, jego pochodzenie i związek z klimatem epoki lodowej, Acta Geologica Polonica, 1, pp. 257-310.

Jamka R., 1964 Fibule typu oczkowatego w Europie Środkowej ze szczególnym uwzględnieniem ziem polskich, Materiały Starożytne, 10, pp. 7-104.

1966 Ciekawe materiały kultury przeworskiej z Rosiejowa, pow. Pińczów, Materiały Archeologiczne, 7 , pp. 155-157.

Jasnosz S., 1952 Cmentarzysko z okresu późnolateńskiego i rzymskiego w Wymysłowie pow. Gostyń, Fontes Praehistorici, 2, pp. 1-284.

Kaczanowski P., Madyda-Legutko R., Poleski J., 1984 Michałowice, Woiwodschaft Kielce, Gemeinde Czarnocin (Brandgräberfeld der Przeworsk-Kultur), Recherches Archéologiques de 1982, pp. $34-37$.

Kaczanowski P., Poleski J., 1985 Dotychczasowe wyniki badań na birytualnym cmentarzysku kultury przeworskiej w Kawczycach, gm. Busko Zdrój, Sprawozdania Archeologiczne, 37, pp. 111-137.

1990 Materiały grobowe kultury przeworskiej z Marzęcina, woj. Kielce, Sprawozdania Archeologiczne, 42, pp. 281-291.

Kogus A., 1963 Cmentarzysko z wczesnego okresu kultury tużyckiej w Nowej Hucie-Pleszowie V, Materiały Archeologiczne, 4, pp. 103-116.

1982 Zespół osadniczy ludności kultury łużyckiej w Krakowie-Pleszowie (Nowa Huta), (in:) M. Gedl (ed.), Południowa strefa kultury łużyckiej i powiązania tej kultury z Południem, Kraków - Przemyśl, pp. 335-349.

Kokowski A., 1989 Miejsce praktyk żałobnych ze schytku starożytności. Strefa sepulkralna cmentarzyska z późnego podokresu lateńskiego, (in:) A. Cofta-Broniewska (ed.), Miejsce pradziejowych i średniowiecznych praktyk kultowych w Kruszy Zamkowej, woj. bydgoskie, stanowisko 13, Poznań, pp. 65-124.

1992 Udzial elementów celtyckich w strukturze cmentarzyska birytualnego w Kruszy Zamkowej, woj. Bydgoszcz, st. 13 (Próba falsyfikacji pojęcia „,grupy kruszańskiej”), Archeologia Polski, 36/1-2 (1991), pp. 115-149.

Konieczny B., 2012 Cmentarzysko oraz zespół osad z epoki brązu i epoki żelaza. Opracowanie materiałów archeologicznych z ratowniczych badań wykopaliskowych na stanowisku Kraków-Bieżanów 30, gm. Kraków, woj. matopolskie, Archives of the Cracow Team for Archaeological Supervision of Motorway Construction (typescript), Kraków.

2014 Cmentarzysko kultury tużyckiej z epoki brazu na stanowisku 10-11 w Targowisku, pow. wielicki, (in:) J. Górski (ed.), Kompleks osadniczy kultury łużyckiej w Targowisku, stan. 10-12, pow. wielicki, Via Archaeologica. Źródła z badań wykopaliskowych na trasie autostrady A4 w Małopolsce, Kraków, pp. 103-180. 
Kostrzewski B., 1947 Cmentarzysko z okresu rzymskiego w Koninie (woj. poznańskie), Przegląd Archeologiczny, 7 (1946-1947), pp. 192-294.

Kościelniak J., 2003 Wykształcenie dolin na Płaskowyżu Proszowickim i ich holoceńska transformacja (na przykładzie zlewni Korycianki), Folia Geographica, Series Geographica-Physica, 33-34, pp. 39-65.

Kozłowska R., 1958 Cmentarzysko z okresu późnolateńskiego i wczesnorzymskiego w Niecieplinie, pow. Garwolin, Materiały Starożytne, 4, pp. 337-365.

Kozłowski L., 1920 Cmentarzysko ciałopalne tuzyckie z III okresu epoki bronzowej na uroczysku Wysyłek w Iwanowicach (pow. miechowski), Wiadomości Archeologiczne, 5, pp. 43-55.

Kruk J., 1971 Próba rekonstrukcji naturalnych warunków rozwoju społeczeństw neolitycznych na obszarze lessów Niecki Nidziańskiej, Sprawozdania Archeologiczne, 22, pp. 259-284.

Kunow J., 1998 Die Hauptserie der Augenfibeln: Gruppe III, Fig. 45-54, (in:) J. Kunow (ed.), 100 Jahre Fibelformen nach Oscar Almgren, Wünsdorf, pp. 93-118.

Lemaniak P., 2006 Zjawisko inhumacji w kulturze przeworskiej (A2-C3/D), Archives of the Institute of Archaeology of the Jagiellonian University (typescript of M.A. Thesis), Kraków.

Liana T., 1970 Chronologia względna kultury przeworskiej we wczesnym okresie rzymskim, Wiadomości Archeologiczne, 35, pp. 429-491.

1976 Ksztaltowanie się stylu B1 w kulturze przeworskiej, (in:) K. Godłowski (ed.), Kultury archeologiczne i strefy kulturowe w Europie Środkowej w okresie wpływów rzymskich, Prace Archeologiczne, 22, pp. 139-151.

Lichardus J., 1984 Körpergräber der frühen Kaiserzeit im Gebiet der südlichen Elbgermanen, Bonn.

Lipkowska A., 2008 Znaleziska zapinek typu A 67 z terenu Wielkopolski, Wielkopolskie Sprawozdania Archeologiczne, 9, pp. 91-102.

Luczkiewicz P., 2010 Rzadki okaz fibuli oczkowatej typu A 45 z Lubelszczyzny: Drążgów, pow. Ryki, woj. lubelskie, (in:) A. Urbaniak, R. Prochowicz, I. Jakubczyk, M. Levada, J. Schuster (eds.), Terra Barbarica. Studia ofiarowane Magdalenie Mączyńskiej w 65. rocznicę urodzin, Monumenta Archaeologica Barbarica, Series Gemina, 2, Łódź - Warszawa, pp. 347-356.

Margos U., 2000 Uwagi na temat genezy obrządku szkieletowego na Pomorzu na przetomie młodszego okresu przedrzymskiego i okresu wplywów rzymskich, (in:) R. Madyda-Legutko, T. Bochnak (eds.), Superiores Barbari. Księga pamiątkowa ku czci Profesora Kazimierza Godłowskiego, Kraków, pp. 255-269.

Mączyńska M., 2001 Das Verbreitungsbild der Fibeln A.67-68 und A.68 im Barbaricum, Slovenská Archeólogia, 49, pp. 165-178.

Miśkiewicz J., 1968 Kultura łużycka w międzyrzeczu Pilicy i środkowej Wisły, Materiały Starożytne, 9, pp. 129-208. 
Naglik R., 2001 „Książę” z Szarbii, Archeologia Żywa, 16, pp. 22-23.

Niewęglowski A., 1981 Obrządek pogrzebowy ludności kultury przeworskiej na przełomie er (II w. p.n.e. - II w. n.e.), Wrocław - Warszawa - Kraków - Gdańsk - Łódź.

Okulicz J., 1965 Plemiona grupy nidzickiej kultury grobów jamowych (w okresie od końca II w. przed nasza erą do $V$ w. n.e.), Warszawa.

Panasewicz W., Taras H., 2007 Depozyt ozdób brązowych ze stan. 1C w Gródku, pow. hrubieszowski, Archeologia Polski Środkowowschodniej, 9, pp. 256-272.

Pearson K., 1899 Mathematical contributions to the theory of evolution. On the reconstruction of the stature of prehistoric races, Philosophical Transactions of the Royal Society of London, 192, 169-244.

Pieta K., 1982 Die Puchov-Kultur, Nitra.

Pikulski J., Zagórska-Telega J., 2011 Obiekty rowkowe na cmentarzysku kultury przeworskiej w Michałowicach, stan. 1, gm. Czarnocin, woj. świętokrzyskie, (in:) E. Droberjar (ed.), Archeologie Barbarů 2010: Hroby a pohřebiště Germánů mezi Labem a Dunajem, Sborník př́spěvků ze VI. Protohistorické konferencje Hradec Králové, 6.-9. září 2010, Olomouc, pp. 207-226.

Potocki J., Woźniak Z., 1959 Niektóre zagadnienia związane z pobytem Celtów w Polsce, Sprawozdania Archeologiczne, 8, pp. 81-98.

Reguła K., 1997 Badania archeologiczne prowadzone przez Muzeum Żup Krakowskich Wieliczka w latach 1995-1996, Studia i Materiały do Dziejów Żup Solnych w Polsce, 20, pp. 199-217.

Rudnicki M., 2006 Importy rzymskie z Petczysk, (in:) E. Droberjar, O. Chvojka (eds.), Archeologie Barbarů 2006, Sborník př́íspěvků z II. protohistorické konference, České Budějovice, pp. 93-112.

Stanek K., 1999 Wisiory opasane odmiany wschodniej w środkowoeuropejskim Barbaricum, (in:) J. Andrzejowski(ed.), COMHLAN. Studia z archeologii okresu przedrzymskiego i rzymskiego w Europie Środkowej dedykowane Teresie Dąbrowskiej w 65. rocznicę urodzin, Warszawa, pp. 331-367.

Steidl B., 2013 Die Augenfibeln Almgren 45-46 in Raetien und den Nordwestprovinzen. Eine Sachform als Spiegel historischer Vorgänge?, (in:) G. Grabherr, B. Kainrath, T. Schierl (eds.), Verwandte in der Fremde. Fibeln und Bestandteile der Bekleidung als Mittel zur Rekonstruktion von interregionalem Austausch und zur Abgrenzung von Gruppen vom Ausgreifen Roms während des 1. Punischen Krieges bis zum Ende des Weströmischen Reiches, Akten des Internationalen Kolloquiums Innsbruck 27. bis 29. IV. 2011, Ikarus, 8, pp. 153-175.

Szydłowski J., 1964 Obrządek pogrzebowy na Górnym Śląsu w okresie wpływów rzymskich, Rocznik Muzeum Górnośląskiego w Bytomiu, Archeologia, 2, Bytom.

Tuszyńska M., 1999 Wybrane zespoty grobowe z zapinkami oczkowatymi typu Almgren 45 z cmentarzysk kultury wielbarskiej nad dolna Wista, (in:) J. Andrzejowski (ed.), COMHLAN. Studia z archeologii okresu przedrzymskiego i rzymskiego w Europie Środkowej dedykowane Teresie Dąbrowskiej w 65. rocznicę urodzin, Warszawa, pp. 369-378. 
Völling, T., 1995 Studien zu Fibelformen der jüngeren vorrömischen Eisenzeit und ältesten römischen Kaiserzeit, Bericht der Römisch-Germanischen Kommission, 75, pp. 147-282.

Wawrzeniecki M., 1908 Poszukiwania archeologiczne w Królestwie Polskim, Materiały AntropologicznoArcheologiczne i Etnograficzne, 10, pp. 64-91.

White T. D., Folkens P. A., 2005 The human bone manual, Burlington - San Diego - London.

Wołągiewicz R., 1970 Napływ importów rzymskich do Europy na pótnoc od środkowego Dunaju, Archeologia Polski, 15/1, pp. 207-252.

1981 Kultura oksywska i wielbarska, (in:) J. Wielowiejski (ed.), Prahistoria Ziem Polskich, 5, Okres lateński i rzymski, Wrocław - Warszawa - Kraków - Gdańsk, pp. 135-191.

Wroniecki P., 2012 Discovery of new Iron Age groove-type features from Michałowice in 2010. A geophysical case study, Recherches Archéologiques Nouvelle Serie, 4, Kraków, pp. 161-170.

Zagórska-Telega J., 2018 Symboliczny czy cząstkowy? Nietypowy obiekt z cmentarzyska kultury przeworskiej w Michałowicach, pow. kazimierski, (in:) B. Niezabitowska-Wiśniewska, P. Łuczkiewicz, S. Sadowski, M. Stasiak-Cyran, M. Erdrich (eds.), Studia Barbarica. Profesorowi Andrzejowi Kokowskiemu w 65. rocznicę urodzin. Tom I, Lublin, pp. 252-264.

Zagórska-Telega J., Bulas J., Pikulski J., Szczepanek A., 2011 Excavations of multicultural site 1 at Michałowice, Czarnocin commune, Świętokrzyskie province, in the years 2008-2010, Recherches Archéologiques Nouvelle Serie, 3, pp. 195-225.

Zagórska-Telega J., Pikulski J., 2014 Uwagi na temat rozplanowania przestrzennego cmentarzyska w Michałowicach. Możliwości interpretacji funkcji obiektów rowkowych, (in:) T. Kurasiński, K. Skóra (eds), Grób w przestrzeni, przestrzeń w grobie, Acta Archaeologica Lodziensia, 60, pp. 69-79.

Zagórska-Telega J., Pikulski J., Bulas J., Szczepanek A., 2012 Excavations on a multicultural site 1 at Michałowice, Czarnocin commune, Świętokrzyskie province, season 2011, Recherches Archéologiques Nouvelle Serie, 4, pp. 135-160.

Zagórska-Telega J., Pikulski J., Szczepanek A., 2014 Pierwszy szkieletowy pochówek ludności kultury przeworskiej odkryty na cmentarzysku w Michałowicach, woj. świętokrzyskie, (in:) R. MadydaLegutko, J. Rodzińska-Nowak (eds.), Honoratissimum assensus genus est armis laudare. Studia dedykowane Profesorowi Piotrowi Kaczanowskiemu z okazji siedemdziesiątej rocznicy urodzin, Kraków, pp. 491-499.

2015 Excavations on a multicultural site 1 at Michałowice, Czarnocin commune, Świętokrzyskie province, season 2012, Recherches Archéologiques Nouvelle Serie, 7, pp. 157-180.

Zyzman A., 2009 Obiekty bez kości na cmentarzyskach grupy tarnobrzeskiej kultury tużyckiej, (in:) S. Czopek, K. Trybała-Zawiślak (eds.), Tarnobrzeska kultura łużycka - Źródła i interpretacje, Collectio Archaeologica Ressoviensis, 11, Rzeszów, pp. 303-309.

Żaki A., 1950 Początki kultury tużyckiej w dorzeczu górnej Wisty, Annales Universitatis Mariae-Curie Skłodowska, Sectio F, 3, pp. 1-214. 
ISSN 0137-3285 